\title{
INOTICES OF MEMAOIRS
}

\section{GEOLOGY OF THE SOUTH-WEST OF ENGLAND.}

1.- "ON the Middle and UPper Lias of the South-west of England." By Charries Moore, F.G.S.

Reprinted from the Proceedings of the Somersetshire Archæological and Natural History Society. Vol. xiii. 1865-66.

2.- " On Abnormal Conditions of Secondary Deposits when conNeCted with the Somersetshire and South Wales CoalBasin; and on the Age of the Sutton and Southerndown Series." By Charles Moore, F.G.S.

Quarterly Journal of the Geological Society, December 1, 1867. Supplementary No. TN the first of these papers, Mr. Moore describes the beds between I the so-called Upper Lias Sands and the zone of Ammonites raricostatus, the highest member of the Lower Lias, in their passage through Somersetshire into Gloucestershire. He gives numerous sections, and lists of fossils, with descriptions and illustrations of the Mollusca,--some of which are new species. A typical section at Ilminster, showing 158 feet of Middle Lias, and 10 feet of Upper Lias, is first explained, and then compared with other sections in the South-west of England. The beds of the Middle Lias consist of irregular thickly-bedded marlstones, marls, and sands, with much ironstone. The Upper Lias comprises thin beds of clay and limestone, crowded with organic remains. Though iron is plentifully distributed in the Middle Lias of the district under consideration, the beds are not quite thick enough to be worked with profit.

In noticing the Ichthyosauri of the Upper Lias, Mr. Moore remarks that whilst these reptiles appear in Liassic times to have fed on the naked cephalopoda, others of this family in their turn retaliated. In several instances their bodies have been found covered by colonies of Ammonites, which were evidently preying upon the Ichthyosauri before they were finally entombed.

Mr. Moore discusses the recent classification with the Upper Lias, of the Yellow Sands beneath the Inferior Oolite, and states that he has never been able to recognize this arrangement. Not only is there in each horizon as distinct a fauna in its general facies as can be found in any other formation, but wherever the junction of the sands with the Upper Lias is observed, there is a most marked and permanent lithological distinction in argillaceous beds crowded with Ammonites, etc., capped by yellow sands, with but few evidences in their lower beds of organic life. Moreover, he adds, that wherever the junction of the Upper Lias with the Sands is exposed, the former presents an eroded surface.

Mr. H. B. Brady contributes a synopsis of the Foraminifera; and Mr. Henry Woodward furnishes a communication on the Crustacea, wherein he points out the interesting fact that many forms, common to the Lias, agree in identity with species found only in the Litho. graphic stone of Solenhofen, showing that they must have migrated 
before the close of the Liassic period in this country, and thus have been enabled to live on during the deposition of the long series of sedimentary deposits which occur between our Lias and the Upper Oolite in Bavaria.

2.-In the second paper, Mr. Moore shows that south of Bath there is a very remarkable thinning-out of the Secondary beds as compared with their equivalents beyond the Mendips, and that whilst in the latter case they attain an aggregate thickness of 3320 feet, in the neighbourhood of Radstock, Paulton, and Camerton they are reduced to 169 feet, which he considers to arise from the Mendip Hills having been a land-area during a great part of this lengthened period, and so serving to prevent the incursion of the Secondary seas within its borders.

The mineral veins of the district show most conclusively that the Carboniferous Limestone must for a very long-extended period have been within the influence of the Liassic seas, and that from the latter have been derived most, if not all, of their mineral treasures, whether iron, lead, or calamine.

Mr. Moore's observations lead him to the conclusion that the elevation of the Mendips and their South Wales continuation may be assigned to a time not far removed from the deposition of the Upper Beds of the Trias or New Red Sandstone. His discovery of a basaltic dyke in the Mendips clearly explains to him the origin of the up-heaval and disturbance of the beds forming this range of hills. A section across the Nettlebridge valley shows that by the protrusion of the dyke rocks of enormous thickness have been carried bodily forward in a northerly direction for a great distance, and are not only left standing vertically, but are in some instances folded over upon themselves. In consequence of this, Coal has been able to be worked beneath a reversed band of Carboniferous Limestone.

In regard to the Sutton Stone, Mr. Moore is of opinion that its peculiar lithology is only local, and he shows that these beds are truly Liassic-a view corroborated by Mr. Bristow's detailed observations in the field. Mr. Moore notices many points of palæontological interest, especially the wonderfully rich fauna of Brocastle, from which he has obtained nearly 200 species, including many Corals which have been examined and described by Dr. Duncan.-H.B.W.

REVIEWS.

Catalogut Systématique et Descriptif des Fossilms des Terrains Tertiares, au Musée Fédéral de Zurich. Cahtugrs 1 and 2. Par Charleg Meyer.

THIS work appears in the Quarterly Journal of the Nat. Hist. 1 Society of Zurich, but its value as a contribution to Palæontology is far greater than its unpretending and somewhat fragmentary mode of publication would imply. It is the result of critical study of species by an experienced and accomplished conchologist, and 